\title{
Geomorphic diversity and landslide susceptibility in the Balason River Basin, Darjeeling Himalaya
}

\author{
Subrata Mondal ${ }^{1}$ and Sujit Mandal ${ }^{2}$ \\ ${ }^{1}$ Geography, A.B.N Seal College, Cooch Behar, India \\ ${ }^{2}$ Geography, Diamond Harbour Women's University, Diamond Harbour, India
}

\begin{abstract}
This study attempts to assess the role of basin morphometric parameters in slope instability using a morphometric diversity (MD) model, as well as the role of drainage parameters and relief parameters in slope failure using drainage diversity (DD) and relief diversity (RD) models, respectively. For this, a total of 14 morphometric data layers were considered. The relationship of each data layer to landslide susceptibility was judged using a frequency ratio (FR) approach. Parameters like drainage density (Dd), drainage frequency (Df), relative relief (Rr), drainage texture (Dt), junction frequency (Jf), infiltration number (In), ruggedness index (Ri), dissection index (Di), elevation (E), slope (S), relief ratio (Rra) and hypsometric integral (Hi) were positively related with landslide potentiality while bifurcation ratio $(\mathrm{Rb})$ and drainage intensity (Din) negatively correlated with S failure. The principal component analysis (PCA)-based weight assigned to each data layer in each model was multiplied with unidirectional reclassified data layers for each model using a weighted linear combination (WLC) approach to prepare landslide susceptibility maps. The receiver operating characteristics curve showed that the landslide prediction accuracy of the DD, RD and MD models were $71.4 \%, 73.9 \%$ and $76.3 \%$, respectively. The FR plots of the aforesaid three models suggested that the chance of landslide increases from very low to very high in susceptible zones.
\end{abstract}

KEYWORDS Relief diversity (RD); drainage diversity (DD); morphometric diversity (MD); weighted linear combination (WIC) approach; landslide susceptibility

CONTACT Subrata Mondal subratapanchagram@gmail.com

Received on 20 November 2017

\section{Introduction}

Landslides are one of the real, normal risks that cause roughly 1,000 individual deaths per year worldwide and around US\$4 billion in property damages in the U.S. (Lee and Pradhan, 2007). The Himalayan mountain regions, the Meghalaya plateau and the Western Ghats are the most significant landslide prone areas in India. The Balason river basin of Darjeeling Himalaya is not an exception to these phenomena, due to its fragile geo-environmental conditions and operating geomorphic process. Every year, a large amount of people, property and the natural environment are affected by landslides. To limit the impact of landslide damages, it is important to predict it before it happens. The landslide susceptibility map has turned out to be an exceptionally valuable approach to assessing, managing and mitigating the landslide hazard for the region (Kienholz, 1978; Spiker and Gori, 2000; Chau et al., 2004). The drainage basin morphometry plays an important role in quantifying the relief, drainage and hydrological conditions which governs the whole landscape of a river basin. The morphometric parameters are intimately associated with landslide activities. These parameters portray the surface chemistry and play vital role in slope instability. Several authors calculated morphometric parameters for terrain analysis using remote sensing (RS) and geographic information system (GIS) in different parts of the world
(Rastogi and Sharma, 1976; Nautiyal, 1994; Magesh et al., 2012). Some researchers tried to find out the ground water potential zones using morphometric parameters (Gajbhiye et al., 2014; Gopal and Saha, 2015). Sub-basin prioritisation (Thakkar and Dhiman, 2007; Amani and Safaviyan, 2015), surface water availability (Rai et al., 2014; Khatun and Pal, 2017), and recharge estimation (Avinash et al., 2014; Nidhi et al., 2016) were done using morphometric parameters. Several studies were established to show the relationship between slope instability or simply landslide occurrences and drainage morphometric parameters (Jeganathan and Chauniyal, 2000; Ghosh, 2015). In this study, a total of 14 morphometric parameters were calculated and spatial data layers were made accordingly. With the help of these parameters, three geomorphic diversity models, i.e. the drainage diversity (DD) model, relief diversity (RD) model and morphometric diversity (MD) model, were applied to prepare landslide susceptibility maps and attempt to gauge how well each model predicts future landslide events. Essentially, highly diversified areas are associated with highly landslide-prone areas and vice versa. The other existing landslide susceptibility methods, such as the frequency ratio (FR) technique (Lee and Talib, 2005; Lee and Sambath, 2006), logistic regression method (Lee and Sambath, 2006; Ghosh et al. 2011), information value (Info Val) method (Anbalagan, 1992), landslide normal risk factor method (Yin and Yin, 1988), discriminant analysis method 
(Gupta and Joshi, 1990), artificial neural network (ANN) method (Choi et al., 2011), neuro-fuzzy method (Pradhan, 2010), support vector machine (Xu et al., 2012), decision tree method (Nefeslioglu, 2010), index of entropy (Devkota et al., 2013), Bayesian probability (Song et al., 2012) and fractal theory (Majtan et al., 2002), etc., were prepared in combination with several relief, drainage, geological, anthropological, protective and triggering factors. But in this study, the three aforementioned diversity models help us discover the role of drainage, relief and morphometric parameters in landslide susceptibility assessment individually. The DD model was calibrated using drainage density (Dd), drainage frequency (Df), bifurcation ratio $(\mathrm{Rb})$, relative relief $(\mathrm{Rr})$, drainage intensity (Din), drainage texture (Dt), junction frequency (Jf), infiltration number (In) and ruggedness index (Ri), whereas the RD model was constructed using slope (S), Rr, dissection index (Di), elevation (E), Ri, Rb, relief ratio (Rra) and hypsometric integral/relative height (Hi). Finally, Dd, Df, Din, Di, Dt, Jf, In, $\mathrm{Rb}, \mathrm{Rr}, \mathrm{Ri}, \mathrm{E}, \mathrm{S}$ and Hi were used for the MD model.

\section{Study area}

The Balason river basin is a section of Bengal's hilly region in Darjeeling Himalaya, situated within latitude $26^{\circ} 40^{\prime} \mathrm{N}-27^{\circ} 01^{\prime} \mathrm{N}$ and longitude $88^{\circ} 7^{\prime} \mathrm{E}-88^{\circ} 25^{\prime} \mathrm{E}$ and covering a geographical area of approximately 378.45 sq. km (Figure 1). The major right bank tributary of the Mahananda River, the Balason River originates from Lepchajagat $(2,361 \mathrm{~m})$, located on the Ghum-Simana ridge. The main leg of the Balason River flows north to south-east for about $51.92 \mathrm{~km}$ and joins the Mahananda River at $26^{\circ} 41^{\prime} 28^{\prime} \mathrm{N}$ and $88^{\circ} 24^{\prime} 15^{\prime} \mathrm{E}$. The total number of streams in the Balason river basin is 3,790 and the total length of all stream segments is $1,476.75 \mathrm{~km}$. The river basin covers parts of Rangli Rangliot, Naxalbari, Matigara, Jorebunglow Sukiapokhri, Mirik and Kurseong in the Darjeeling district in West Bengal. The Balason river basin of Darjeeling Himalaya is characterised by a distinct geographical environment. The evolution of landforms is largely dependent on its geological structure, lithology, relief configuration, climatic characteristics and biophysical processes. The elevation of the region increases from south to north, $121 \mathrm{~m}$ at Matigara but 2,416 $\mathrm{m}$ at Lepchajagat. The network created by different ridges and valleys shows a dendritic drainage pattern. Inclination of slope is different in various parts of the basin. Some areas in the northern part have an inclination of $30^{\circ}-45^{\circ}$, whereas other places, especially in the south, have an inclination of $15^{\circ}-30^{\circ}$. The river valley has a steep, ungraded channel, narrow floor, steep valley, etc. in the upper portion of the basin. The gradient of the river is controlled by lithology and mass movement of the area. The steep slopes and high altitude, especially in the north, make these areas vulnerable to slope instability, whereas southern parts of the basin are less vulnerable due to the lower altitude and slope gradient. Most of the area of this basin is covered by intensely metamorphosed rocks like gneiss, slates, phyllite and schists, etc. These rocks are characterised by several fractures, joints and faults. They are also highly weathered. Such conditions maximise the chances of landslide occurrences. Inceptisol order soils cover almost the entire hilly tract of the Balason river basin, and are characterised by moderately shallow, well-drained, gravelly loamy soils with a loamy surface and moderate to severe erosion, etc., which makes the areas more vulnerable to slope instability. About $85 \%$ of the annual rainfall occurs due to the southwest monsoon. Hilly regions of the basin experience more rainy days (124 days) than plain regions (100 days), often more than $2.5 \mathrm{~mm}$ rainfall in a single day. The hilly region also receives more rainfall than the plains. The whole basin receives an average of 2,300 $\mathrm{mm}$ (2,000 mm - 5,000 mm) of rainfall (Lama, 2003; Mondal and Mandal, 2017a). The mean temperature of the Balason river basin is not the same in the upper part of the region. About $12^{\circ} \mathrm{C}$ mean annual temperature can be observed in the hilly region, whereas the recorded mean annual temperature in the plain region is $24^{\circ} \mathrm{C}$. In summer, the mean temperature ranges from $27^{\circ} \mathrm{C}-29^{\circ} \mathrm{C}$ in the plains and from $16^{\circ} \mathrm{C}-22^{\circ} \mathrm{C}$ in the hills, whereas mean winter temperatures range from $12^{\circ} \mathrm{C}-14^{\circ} \mathrm{C}$ in the plains and $5^{\circ} \mathrm{C}$ $7^{\circ} \mathrm{C}$ in the hills (Lama, 2003).

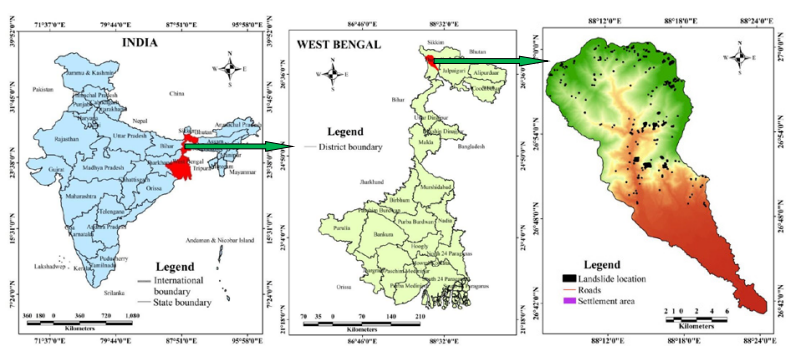

Figure 1. Location map of the study area.

\section{Materials and methods}

In the present study, a total of 14 parameters such as Dd, Df, Rb, Rr, Din, Dt, Jf, In, Ri, Di, E, S, Rra and Hi were considered for the landslide susceptibility assessment and prediction, which were prepared from Shuttle Radar Topography Mission Digital Elevation Model, Toposheets and Google Earth imagery (Table 1). Various classification methods exist, such as quantile, equal interval, natural break and standard deviation methods, to classify the aforesaid data layers (Pradhan and Lee, 2010a). If the data distribution has a positive or negative skew, the quantile or natural break distribution classifiers can be chosen (Akgun et al. 2012). As suggested by many researchers, the natural break method was applied to determine different subclasses (Althuwaynee et al., 2014; Shrestha et al., 2017; Mandal and Mandal, 2017) for this study. 
Table 1. Dataset used in the study.

\begin{tabular}{|c|c|c|}
\hline Purpose & Data used & Data source \\
\hline $\begin{array}{l}\text { Preparation of landslide } \\
\text { inventory map }\end{array}$ & $\begin{array}{l}\text { Google earth historical imageries } \\
\text { (2000 - 2016), Landsat 7 ETM+ } \\
\text { imageries (2000 - 2005), Landsat } \\
4 \text { - } 5 \text { TM imageries (2006 - 2007, } \\
2009 \text { - 2011), LISS III imageries } \\
\text { (2008, 2012 - 2013), Landsat } 8 \\
\text { OLI (2014 - 2015), high resolution } \\
\text { Sentinel-2 imagery (2016), Arc Map } \\
\text { high resolution world imagery and } \\
\text { intensive field survey data (2015 - } \\
\text { 2016). }\end{array}$ & \begin{tabular}{|l|} 
https://earthexplorer.usgs. \\
gov/, https://glovis.usgs. \\
gov, http://bhuvan.nrsc.gov. \\
in/, Google earth, Arc Map \\
10.1 world imagery and Field \\
investigation using GPS \\
\end{tabular} \\
\hline $\begin{array}{l}\text { Preparation of Rr, Di, E, S, } \\
\text { Hi data layers }\end{array}$ & $\begin{array}{l}\text { SRTM DEM (30 m spatial } \\
\text { resolution) (2014) }\end{array}$ & earthexplorer.usgs.gov \\
\hline $\begin{array}{l}\text { Thematic data layers of Dd, } \\
\mathrm{Df}, \mathrm{Rb} \text {, Din, Dt, Jf and In }\end{array}$ & $\begin{array}{l}\text { Toposheet }(1961-1962,1965- \\
1966,1969-1971) \text { and Google } \\
\text { earth imagery }(2015)\end{array}$ & $\begin{array}{l}\text { Survey of India }(\mathrm{SOI}), \\
\text { Kolkata. toposheet no. } 78 \mathrm{~A} / 4, \\
78 \mathrm{~A} / 8,78 \mathrm{~B} / 1,78 \mathrm{~B} / 5 \text { and } \\
78 \mathrm{~B} / 6 \text { and Google earth map }\end{array}$ \\
\hline Data layers of Ri and Rra & $\begin{array}{l}\text { SRTM DEM (30 m spatial } \\
\text { resolution) and Toposheet (1961- } \\
62,1965-66,1969-71) \text { and Google } \\
\text { earth imagery (2015) }\end{array}$ & \begin{tabular}{|l|} 
earthexplorer.usgs.gov, \\
Survey of India (SOI), \\
Kolkata. toposheet no. $78 \mathrm{~A} / 4$, \\
$78 \mathrm{~A} / 8,78 \mathrm{~B} / 1,78 \mathrm{~B} / 5$ and \\
$78 \mathrm{~B} / 6$ and Google earth map
\end{tabular} \\
\hline
\end{tabular}

\subsection{Preparation of landslide inventory map}

A landslide inventory map is the preliminary step in preparing landslide susceptibility map. Several researchers incorporated aerial photographs and satellite images to identify different locations of landslide events (Lee and Pradhan, 2007; Pradhan, 2010; Choi et al., 2011). In this study, Google Earth historical imageries (2000 - 2016), Landsat 7 enhanced thematic mapper plus (ETM+) imageries (2000 - 2005), Landsat 4 - 5 thematic mapper (TM) imageries (2006 - 2007, 2009 - 2011), linear imaging self-scanning sensors (LISS) III imageries (2008, 2012 2013), Landsat 8 operational land imager (OLI) (2014 2015), high resolution Sentinel-2 imagery (2016), Arc Map high resolution world imagery and intensive field survey data (2015 - 2016) were used in the mapping of several large and small landslides. There are three major types of landslide identified in the study area - shallow translational debris slides, deep-seated rockslides and shallow translational rockslides. A total of 295 landslide locations were mapped (Figure 1) and randomly divided into two parts, i.e. $70 \%$ of the total landslide locations were used as a training data set and the remaining $30 \%$ of locations were used for validation of the model. The average area of landslide was $3,762.90 \mathrm{~m}^{2}$.

\subsection{Preparation of morphometric data layers and their role in slope instability}

A total of 14 parameters were calculated using a recognised formula and prepared spatial data layers in Arc GIS environment. The relationship between morphometric parameters and landslide occurrences were judged using a FR approach (Karim et al., 2011; Mondal and Mandal, 2017a),

$$
\mathrm{FR}=\frac{\{N \operatorname{pix}(S i) / N \operatorname{pix}(N i)\} * 100}{\left\{\sum N \operatorname{pix}(S i) / \sum N \operatorname{pix}(N i)\right\} * 100} .
$$

Where $N$ pix (Si) is the number of pixels containing landslide in each class $(i), N$ pix $(N i)$ is the total number of pixels having class (i) in the whole basin, $\sum N$ pix $(S i)$ is the total number of pixels in each class and $\sum N$ pix $(\mathrm{Ni})$ is the total number of pixels in the whole basin. The higher the FR value, the greater the chance of landslide occurrences.

\subsection{1. $\mathrm{Dd}$}

This is an important factor in landslide susceptibility. Dd means the total stream length per unit area. It also indicates the closeness of spacing of channel per unit area, which determines the landscape dissection and runoff potentiality of a region (Strahler, 1964). Dd indirectly presents the erosional status of the basin and highly correlates with landslide susceptibility. Higher Dd in an area indicates a high landslide probability and lower Dd means the opposite (Sarkar and Kanungo, 2004). High Dd implies high runoff and consequently low infiltration rate, whereas low Dd implies low runoff and consequently high infiltration. In this study, Dd varies from $0 \mathrm{~km} /$ sq. $\mathrm{km}-15.10 \mathrm{~km} / \mathrm{sq}$. $\mathrm{km}$ and was classified into 10 different classes, i.e. $0 \mathrm{~km} / \mathrm{sq} . \mathrm{km}-1.31 \mathrm{~km} / \mathrm{sq} . \mathrm{km}$, $1.31 \mathrm{~km} / \mathrm{sq} . \mathrm{km}-2.61 \mathrm{~km} / \mathrm{sq} . \mathrm{km}, 2.61 \mathrm{~km} / \mathrm{sq}$. km $3.67 \mathrm{~km} / \mathrm{sq} . \mathrm{km}, 3.67 \mathrm{~km} / \mathrm{sq} . \mathrm{km}-4.56 \mathrm{~km} / \mathrm{sq}$. km, $4.56 \mathrm{~km} / \mathrm{sq} . \mathrm{km}-5.39 \mathrm{~km} / \mathrm{sq} . \mathrm{km}, 5.39 \mathrm{~km} / \mathrm{sq} . \mathrm{km}-$ $6.27 \mathrm{~km} / \mathrm{sq} . \mathrm{km}, 6.27 \mathrm{~km} / \mathrm{sq} . \mathrm{km}-7.28 \mathrm{~km} / \mathrm{sq} . \mathrm{km}$, $7.28 \mathrm{~km} / \mathrm{sq} . \mathrm{km}-8.58 \mathrm{~km} / \mathrm{sq}$. km, $8.58 \mathrm{~km} / \mathrm{sq}$. km $10.60 \mathrm{~km} / \mathrm{sq} . \mathrm{km}$ and $10.60 \mathrm{~km} / \mathrm{sq} . \mathrm{km}-15.10 \mathrm{~km} / \mathrm{sq} . \mathrm{km}$ (Figure 2(a)).

\subsection{2. $D f$}

Df is an important geomorphic concept which measures the relative spacing of drainage lines. The term refers to the number of stream segments of all orders per unit area (Horton, 1945). It helps for understanding the drainage texture as well as the texture of the landscape of an area. High Df indicates fast runoff and therefore landslide susceptibility is more likely in a basin with high stream frequency (Jeganathan and Chauniyal, 2000). In this study, Df was grouped into 10 classes: 0 streams/sq. km - 4.91 streams/sq. km, 4.91 streams/sq. km 11.05 streams/sq. km, 11.05 streams/sq. km 15.96 streams/sq. km, 15.96 streams/sq. km 21.27 streams/sq. km, 21.27 streams/sq. km 27.00 streams/sq. km, 27.00 streams/sq. km 33.54 streams/sq. km, 33.54 streams/sq. km 40.90 streams/sq. km, 40.90 streams/sq. km 52.35 streams/sq. km, 52.35 streams/sq. km 70.35 streams/sq. $\mathrm{km}$ and 70.35 streams/sq. km 104.30 streams/sq. km (Figure 2(b)).

\subsection{3. $R b$}

$\mathrm{Rb}$ is a dimensionless property of the drainage basin that may be defined as the ratio between the total number of stream segments of an order and the next higher order 
(Horton, 1945). It is strongly controlled by Dd, lithological characteristics, basin shape and area, and stream entrance angle, etc. A higher Rb means structurally disturbed watersheds with high distortion in drainage pattern indicate a highly landslide prone area (Ghosh, 2015). The Rb of the Balason river basin ranges from $1.50-5.66$ and it was reclassified into eight classes, i.e. 1.50 - 2.56, 2.56 - 3.25, 3.25 - 3.71, 3.71 - 4.01, 4.01 - 4.22, 4.22 - 4.52, 4.52 - 4.98 and $4.98-5.66$ (Figure 2(c)).

\subsection{4. $R r$}

$\mathrm{Rr}$ is another important parameter in the preparation of a landslide susceptibility zonation map (Mandal and Mandal, 2016). It can be defined as the difference between highest altitude and lowest altitude. The $\mathrm{Rr}$ is positively associated with landslide susceptibility. High Rr enhances the chance of slope failure and vice versa (Jeganathan and Chauniyal, 2000). For the present study, the $\mathrm{Rr}$ value ranges from $5.19 \mathrm{~m} / \mathrm{sq}$. $\mathrm{km}-662.00 \mathrm{~m} / \mathrm{sq}$. km and is divided into 10 different classes, i.e. $5.19 \mathrm{~m} / \mathrm{sq} . \mathrm{km}$ $51.70 \mathrm{~m} / \mathrm{sq} . \mathrm{km}, 51.70 \mathrm{~m} / \mathrm{sq} . \mathrm{km}-127.00 \mathrm{~m} / \mathrm{sq} . \mathrm{km}$, $127.00 \mathrm{~m} / \mathrm{sq} . \mathrm{km}-215.00 \mathrm{~m} / \mathrm{sq} . \mathrm{km}, 215.00 \mathrm{~m} / \mathrm{sq} . \mathrm{km}-$ $292.00 \mathrm{~m} / \mathrm{sq} . \mathrm{km}, 292.00 \mathrm{~m} / \mathrm{sq} . \mathrm{km}-346.00 \mathrm{~m} / \mathrm{sq} . \mathrm{km}$, $346.00 \mathrm{~m} / \mathrm{sq}$. km - $393.00 \mathrm{~m} / \mathrm{sq}$. km, $393.00 \mathrm{~m} / \mathrm{sq} . \mathrm{km}-$ $434.00 \mathrm{~m} / \mathrm{sq} . \mathrm{km}, 434.00 \mathrm{~m} / \mathrm{sq} . \mathrm{km}-475.00 \mathrm{~m} / \mathrm{sq} . \mathrm{km}$, $475.00 \mathrm{~m} / \mathrm{sq} . \mathrm{km}-532.00 \mathrm{~m} / \mathrm{sq} . \mathrm{km}$ and $532.00 \mathrm{~m} / \mathrm{sq} . \mathrm{km}-$ $662.00 \mathrm{~m} / \mathrm{sq}$. km (Figure 2(d)).

\subsubsection{Din}

Din may be defined as the ratio of Df to Dd (Faniran, 1968). A high Din value indicates that Dd and stream frequency have significant influence on the degree to which the land surface of the watershed has been lowered by various denudation processes. Simply put, high Din areas are characterised by more slope failure events. The Din of the study area ranges from $0-48.17$ and was reclassified into 10 categories, i.e. 0 - $1.51,1.51$ - 3.02, 3.02 - 4.16, 4.06 - 5.67, 5.67 - 8.12, 8.12 - 12.10, 12.10 - 17.96, 17.96 25.51, 25.51 - 34.58 and 34.58 - 48.17 (Figure 2(e)).

\subsection{6. $D t$}

Dt denotes the total number of stream segments of all orders per perimeter of that area (Horton, 1945). It indicates the relative spacing of drainage lines and the cumulative effect of the infiltration capacity, the amount and type of vegetation, infiltration capacity and relief aspect of the terrain, which influences the rate of surface runoff and affects the Dt of a basin. A high textural area indicates greater susceptibility of landslide occurrences (Jeganathan and Chauniyal, 2000). In this study, the value of the Dt ranges from 0 streams $/ \mathrm{km}$ - 26.07 streams $/ \mathrm{km}$ and is categorised into 10 classes, i.e. 0 streams $/ \mathrm{km}-1.23$ streams $/ \mathrm{km}$, 1.23 streams $/ \mathrm{km}$ - 2.76 streams $/ \mathrm{km}, 2.76$ streams $/ \mathrm{km}$ 3.99 streams $/ \mathrm{km}, 3.99$ streams $/ \mathrm{km}$ - 5.32 streams $/ \mathrm{km}$,
5.32 streams $/ \mathrm{km}$ - 6.75 streams $/ \mathrm{km}, 6.75$ streams $/ \mathrm{km}$ 8.38 streams $/ \mathrm{km}, 8.38$ streams $/ \mathrm{km}$ - 10.23 streams $/ \mathrm{km}$, 10.23 streams $/ \mathrm{km}$ - 13.10 streams $/ \mathrm{km}, 13.10$ streams $/ \mathrm{km}$ 17.59 streams $/ \mathrm{km}$ and 17.59 streams $/ \mathrm{km}-26.07$ streams $/ \mathrm{km}$ (Figure 2(f)).

\subsection{7. $J f$}

This is the number of stream nodes per unit area (Ghosh and Saha, 2015). It reflects the hydrological condition of a basin. The higher the Jf value, the greater chance of water availability. The river erosional process leads to the slope becoming more vulnerable. Simply put, it enhances the chance of landslide occurrences (Jeganathan and Chauniyal, 2000). The Jf value ranges from 0 stream nodes $/ \mathrm{sq} . \mathrm{km}$ 67.49 stream nodes/sq.km and is grouped into 10 classes, i.e. - 0 stream nodes/sq.km - 2.38 stream nodes $/ \mathrm{sq.km}$, 2.38 stream nodes/sq.km - 5.82 stream nodes $/$ sq. km, 5.82 stream nodes/sq.km - 9.00 stream nodes $/ \mathrm{sq} . \mathrm{km}$, 9.00 stream nodes/sq.km - 12.45 stream nodes/sq.km, 12.45 stream nodes/sq.km - 16.42 stream nodes/sq.km, 16.42 stream nodes/sq.km - 20.92 stream nodes/sq.km, 20.92 stream nodes/sq.km - 26.74 stream nodes/sq.km, 26.74 stream nodes/sq.km - 34.95 stream nodes/sq.km, 34.95 stream nodes/sq. km - 46.33 stream nodes/sq.km and 46.33 stream nodes/sq.km - 67.49 stream nodes/sq.km (Figure 2(g)).

\subsubsection{In}

The In of a drainage basin is the product of Dd and stream frequency (Faniran, 1968). The higher the In, the lower the infiltration and the higher the runoff will be. Therefore, a high In is closely associated with slope instability (Ghosh, 2015). In values were reclassified into 10 classes, i.e. 0 In/sq.km - $30.89 \mathrm{In} / \mathrm{sq} . \mathrm{km}, 30.89 \mathrm{In} /$ sq.km - $80.32 \mathrm{In} / \mathrm{sq} . \mathrm{km}, 80.32 \mathrm{In} / \mathrm{sq} . \mathrm{km}-148.28 \mathrm{In} / \mathrm{sq} . \mathrm{km}$, $148.28 \mathrm{In} / \mathrm{sq} . \mathrm{km}$ - $234.78 \mathrm{In} / \mathrm{sq} . \mathrm{km}, 234.78 \mathrm{In} / \mathrm{sq.km}$ $339.81 \mathrm{In} / \mathrm{sq} . \mathrm{km}, 339.81 \mathrm{In} / \mathrm{sq} . \mathrm{km}$ - $481.92 \mathrm{In} / \mathrm{sq} . \mathrm{km}$, $481.92 \mathrm{In} / \mathrm{sq} . \mathrm{km}$ - $667.27 \mathrm{In} / \mathrm{sq} . \mathrm{km}, 667.27 \mathrm{In} / \mathrm{sq} . \mathrm{km}$ $883.51 \mathrm{In} / \mathrm{sq} . \mathrm{km}, 883.51 \mathrm{In} / \mathrm{sq} . \mathrm{km}$ - 1,130.66 In/sq.km and 1,130.66 In/sq.km - 1,575.50 In/sq.km (Figure 2(h)).

\subsection{9. $R i$}

Topographic ruggedness exhibits significant control over the spatial occurrence of landslides and erosion prone areas, and portrays the intricate relationship of lithology, structure, relief and climate. It is the product of Dd and basin relief divided by 1,000 (Miller et al., 1990). The low ruggedness value of the basin implies that the area is less prone to soil erosion and landslide, and has intrinsic structural complexity in association with relief and Dd. In the study, this figure ranges from $0 \mathrm{Ri} / \mathrm{sq} . \mathrm{km}-6.55 \mathrm{Ri} / \mathrm{sq} . \mathrm{km}$, which is partitioned into 10 groups, i.e. $0 \mathrm{Ri} / \mathrm{sq} . \mathrm{km}-$ .34 Ri/sq. km, .34 Ri/sq. km - .93 Ri/sq. km, .93 Ri/sq. km - 
$1.42 \mathrm{Ri} / \mathrm{sq} . \mathrm{km}, 1.42 \mathrm{Ri} / \mathrm{sq} . \mathrm{km}-1.83 \mathrm{Ri} / \mathrm{sq} . \mathrm{km}, 1.83 \mathrm{Ri} / \mathrm{sq} . \mathrm{km}$ $2.22 \mathrm{Ri} / \mathrm{sq}$. km, $2.22 \mathrm{Ri} / \mathrm{sq} . \mathrm{km}-2.63 \mathrm{Ri} / \mathrm{sq} . \mathrm{km}$, $2.63 \mathrm{Ri} / \mathrm{sq} . \mathrm{km}-3.12 \mathrm{Ri} / \mathrm{sq} . \mathrm{km}, 3.12 \mathrm{Ri} / \mathrm{sq} . \mathrm{km}-3.74 \mathrm{Ri} / \mathrm{sq} . \mathrm{km}, 3$ $.74 \mathrm{Ri} / \mathrm{sq} . \mathrm{km}-4.48 \mathrm{Ri} / \mathrm{sq} . \mathrm{km}$ and $4.48 \mathrm{Ri} / \mathrm{sq} . \mathrm{km}-$ $6.55 \mathrm{Ri} / \mathrm{sq}$. km (Figure 2(i)).

\subsubsection{0. $\mathrm{Di}$}

The Di depicts the degree of dissection or vertical erosion, and the stage of landform development in a basin watershed. It may be defined as the ratio between the relative relief and absolute relief of the basin (Nir, 1957) and the value always ranges between 0.0 (complete absence of dissection and thus the dominance of flat topography) and 1 for infrequent cases such as vertical cliff topography at the sea shore or vertical escarpment of hill slope (Farhan et al., 2015). A high Di enhances the chance of S failure and vice versa (Jeganathan and Chauniyal, 2000; Ghosh, 2015). In this study, 10 classes of dissection index were made: $.06 \mathrm{Di} / \mathrm{sq} . \mathrm{km}$ - $.13 \mathrm{Di} / \mathrm{sq} . \mathrm{km}, 13 \mathrm{Di} / \mathrm{sq} . \mathrm{km}-.17 \mathrm{Di} / \mathrm{sq} . \mathrm{km}$, $.17 \mathrm{Di} / \mathrm{sq} . \mathrm{km}-.22 \mathrm{Di} / \mathrm{sq} . \mathrm{km}, .22 \mathrm{Di} / \mathrm{sq} . \mathrm{km}-.26 \mathrm{Di} / \mathrm{sq} . \mathrm{km}$, $.26 \mathrm{Di} / \mathrm{sq} . \mathrm{km}-.31 \mathrm{Di} / \mathrm{sq} . \mathrm{km}, .31 \mathrm{Di} / \mathrm{sq} . \mathrm{km}-.37 \mathrm{Di} / \mathrm{sq} . \mathrm{km}$, $.37 \mathrm{Di} / \mathrm{sq} . \mathrm{km}-.42 \mathrm{Di} / \mathrm{sq} . \mathrm{km}, .42 \mathrm{Di} / \mathrm{sq} . \mathrm{km}-.47 \mathrm{Di} / \mathrm{sq} . \mathrm{km}$, $.47 \mathrm{Di} / \mathrm{sq} . \mathrm{km}-.52 \mathrm{Di} / \mathrm{sq} . \mathrm{km}$ and $.52 \mathrm{Di} / \mathrm{sq} . \mathrm{km}-$ $.59 \mathrm{Di} / \mathrm{sq} . \mathrm{km}$ (Figure 2(j)).

\subsubsection{1. $E$}

E is the primary causative factor which affects the slope material through the weathering process. It has a direct influence on all others topographic aspects, slope, soil layer arrangement, etc. As the elevation increases, the slope angle also increases, which directly makes the land surface more landslide susceptible (Devkota et al., 2013). In this study, the E value ranges from $106 \mathrm{~m}-2,600 \mathrm{~m}$ and is divided into 10 classes, i.e. $106 \mathrm{~m}-298 \mathrm{~m}, 298 \mathrm{~m}-539 \mathrm{~m}$, $539 \mathrm{~m}-792 \mathrm{~m}, 792 \mathrm{~m}-1,030 \mathrm{~m}, 1,030 \mathrm{~m}-1,240 \mathrm{~m}$, $1,240 \mathrm{~m}-1,440 \mathrm{~m}, 1,440 \mathrm{~m}-1,650 \mathrm{~m}, 1,650 \mathrm{~m}-1,880 \mathrm{~m}$, $1,880 \mathrm{~m}-2,130 \mathrm{~m}$ and 2,130 $\mathrm{m}-2,600 \mathrm{~m}$ (Figure 2(k)).

\subsubsection{2. $S$}

$\mathrm{S}$ is a key factor which strongly influences the landslide susceptibility of a region. A positive correlation exists between landslides and $\mathrm{S}$ which indicates that areas with steep S are more prone to landslide occurrences (Mandal and Mandal, 2018). As the S angle increases, the tendency of movement increases and shear stress in soil and other unconsolidated material generally increases. Moderate $\mathrm{S}$ is expected to have a low frequency of landslide (Ayalew et al., 2005). The $\mathrm{S}$ of the basin ranges from $0^{\circ}-71.10^{\circ}$ and was reclassified into 10 classes, i.e. $0^{\circ}-5.03^{\circ}, 5.03^{\circ}-11.30^{\circ}$, $11.30^{\circ}-16.80^{\circ}, 16.80^{\circ}-21.90^{\circ}, 21.90^{\circ}-26.60^{\circ}, 26.60^{\circ}$ $31.10^{\circ}, 31.10^{\circ}-35.50^{\circ}, 35.50^{\circ}-40.60^{\circ}, 40.60^{\circ}-47.00^{\circ}$ and $47.00^{\circ}-71.10^{\circ}$ (Figure 2(1)).
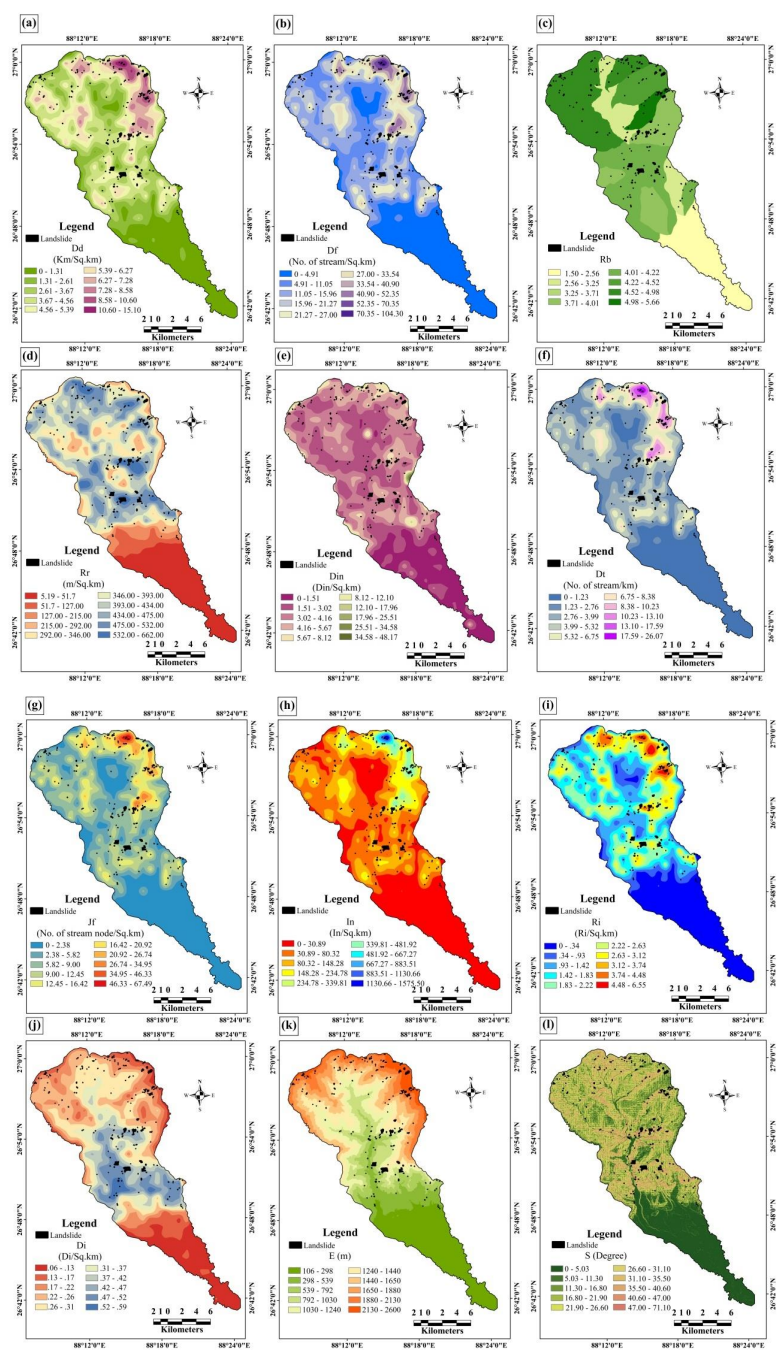

Figure 2. Spatial data layers of (a) Dd; (b) Df; (c) Rb; (d) Rr; (e) Din; (f) Dt; (g) Jf; (h) In; (i) Ri; (j) Di; (k) E; and (l) S.

\subsubsection{Rra}

Rra is an index of relief characteristics and steepness in a drainage basin. It refers to the difference in height between the highest and lowest points in the basin and the horizontal distance along the longest dimension of the basin parallel to the main stream line (Schumm, 1956). The ratio is positively correlated with the rate of erosion in the basin and the value of the Rra normally increases with decreasing drainage area and size of a given catchment. In this study, the Rra varies from $.02-.30$ and was classified into 10 different classes, i.e. $.02, .02-.11, .11-.14, .14-.18, .18-.20, .20-.21, .21-.22$, $.22-.23, .23-.27$ and $.27-.30$ (Figure 3(a)).

\subsubsection{4. $\mathrm{Hi}$}

Hypsometrics are related to the measurement and analysis of relationships between altitude and basin area. It helps for understanding the degree of dissection and stage of erosion of a basin (Strahler, 1952). The Hi indicates the 
percentage area under the dimensionless curve as a good indicator of the basin erosional status or the surface decay, whereas the erosional integral is the area proportionate to the area above the curve. The high value of the Hi denotes the active erosional youthful stage of the basin, which is more slide prone (Ghosh, 2015). The Hi map of the study area was divided into 10 classes, i.e. .18 - .31, .31 - .37, $.37-.41, .41-.44, .44-.48, .48-.51, .51-.54, .54-.57$, $.57-.62$ and $.62-.75$ (Figure 3(b)).
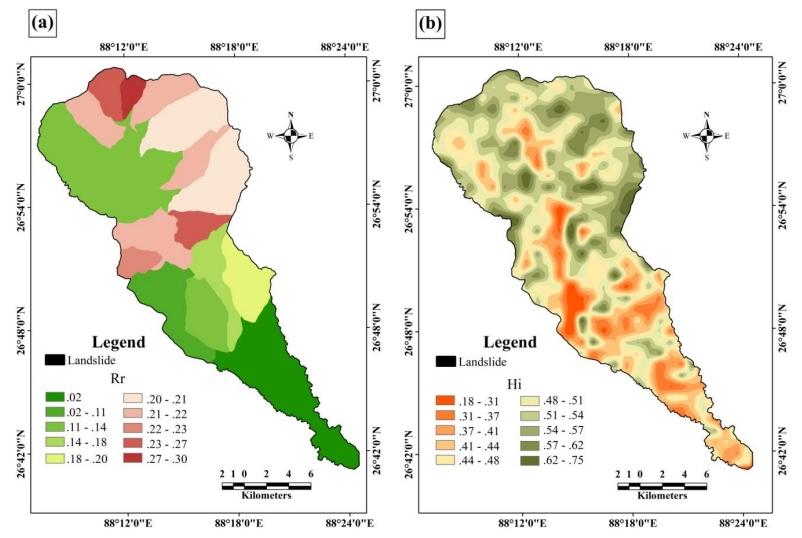

Figure 3. Spatial data layers of (a) Rra and (b) Hi.

\subsection{Uniform scaling and assigning principal component analysis (PCA)-based weight for constructing DD, RD and MD models and landslide susceptibility zonation mapping}

After preparing the morphometric data layers in GIS platform, DD, RD and MD models were used for landslide susceptibility zonation mapping (Table 2). Some parameters are common because these parameters directly or indirectly represent both the relief and drainage character, such as $\mathrm{Rb}$ which indicates the drainage characteristics and break of $\mathrm{S}$ characteristics. In the same way, Ri implies the arrangement of a drainage network and ruggedness characteristics of relief.

Table 2. Spatial data layers and composite equations used in $\mathrm{RD}, \mathrm{DD}$ and MD methods.

\begin{tabular}{|c|c|c|c|}
\hline Method & $\begin{array}{l}\text { Number of } \\
\text { spatial data } \\
\text { layers }\end{array}$ & $\begin{array}{l}\text { Name of } \\
\text { spatial data } \\
\text { layers }\end{array}$ & Composite equation \\
\hline DD & 9 & $\begin{array}{l}\text { Dd, Df, Rb, } \\
\text { Rr, Din, Dt, } \\
\text { Jf, In and Ri }\end{array}$ & $\begin{array}{l}\text { DD Model }=(\text { Reclass of } \mathrm{Dd} \times 1.000)+(\text { Reclass of } \mathrm{Df} \times 1.000)+ \\
(\text { Reclass of } \mathrm{Rb} \times 0.707)+(\text { Reclass of } \mathrm{Rr} \times 0.769)+(\text { Reclass of Din } \times \\
0.638)+(\text { Reclass of } \mathrm{Dt} \times 1.000)+(\text { Reclass of Jf } \times .0 .971)+(\text { Reclass of } \\
\text { In } \times \quad 0.891)+\quad \text { (Reclass of Ri } \\
0.967)\end{array}$ \\
\hline $\mathrm{RD}$ & 8 & $\begin{array}{l}\text { S, Rr, Di, E, } \\
\text { Ri, Rb, Rra } \\
\text { and } \mathrm{Hi}\end{array}$ & $\begin{array}{l}\text { RD Model }=(\text { Reclass of } \mathrm{S} \times 0.811)+(\text { Reclass of } \mathrm{Rr} \times 1.000)+(\text { Reclass } \\
\text { of } \mathrm{Di} \times 0.588)+(\text { Reclass of Altitude } \times 0.851)+(\text { Reclass of } \mathrm{Ri} \times 0.890) \\
+(\text { Reclass of } \mathrm{Rb} \times 0.831)+(\text { Reclass of Rra } \times 0.878)+(\text { Reclass of } \mathrm{Hi} \times \\
0.602)\end{array}$ \\
\hline MD & 13 & $\begin{array}{l}\text { Dd, Df, Din, } \\
\text { Di, Dt, Jf, } \\
\text { In, Rb, Rr, } \\
\text { Ri, E, S and } \\
\text { Hi }\end{array}$ & $\begin{array}{l}\text { MD Model }=(\text { Reclass of } \mathrm{Dd} \times 1.000)+(\text { Reclass of } \mathrm{Df} \times 0.981)+ \\
(\text { Reclass of Din } \times 0.671)+(\text { Reclass of } \mathrm{Di} \times 0.452)+(\text { Reclass of } \mathrm{Dt} \times \\
0.981)+(\text { Reclass of } \mathrm{Jf} \times 0.935)+(\text { Reclass of } \mathrm{In} \times 0.836)+(\text { Reclass of } \\
\mathrm{Rb} \times 0.765)+(\text { Reclass of } \mathrm{Rr} \times 0.895)+(\text { Reclass of } \mathrm{Ri} \times 1.000)+ \\
(\text { Reclass of Altitude } \times 0.848)+(\text { Reclass of } \mathrm{S} \times 0.720)+(\text { Reclass of Hyi } \\
\times 0.527)\end{array}$ \\
\hline
\end{tabular}

To perform the aforesaid three model analysis, principal compoent analysis (PCA)-based weights were assigned to each data layer of each mode. PCA-based weight was also used by Khatun and Pal (2017). It was calculated using Equation (2),

$$
W m=\frac{\sum a m r}{\sum a n r \max }
$$

Where $W m$ is the weight of the $m$ th parameter, amris the row wise summation of correlation coefficient of the $m$ th parameter (avoiding the minus symbol) and anr max is the maximum correlation coefficient within the total parameter.

The preparation of a landslide susceptibility map requires that the factors considered be combined with respect to their relative importance in landslide occurrence (Sarkar and Kanungo, 2004). The intra-class ranking of 14 parameters was done based on a 10-point scale to make the parameters unidirectional in terms of landslide susceptibility, with 10 points assigned to the class which enhances the chance of landslide occurrences of each data layer. Except the $\mathrm{Rb}$ data layer, all the data layers were divided into 10 classes to simplify the workflow. After giving each its relative importance on the 10-point scale (Table 3), each unidirectional and reclassified data layer was multiplied with the individual PCA-based parameter weight and finally summed up by the weighted linear combination method (WLCM),

$$
\mathrm{WLCM}=\sum_{j=1}^{n} a j \times w j .
$$

Where $a j$ is the unidirectional and reclassified data layer of the $j$ th attribute, $w j$ is the PCA-based weight of the $j$ th attribute.

\subsection{Validation methods}

Two well recognised validation methods were employed in this study, i.e. the receiver operating characteristics (ROC) curve and FR. Several researchers used the ROC curve for the accuracy assessment of the landslide susceptibility map (Bui et al.,2012; Ozdemir and Altural, 2013). The ROC curve is the graphical presentation of the sensitivity on the $y$ axis and 1-specificity of the model on the $\mathrm{x}$ axis (Mohammady et al., 2012). The area under curve (AUC) value of the ROC curve varies from 0.5 - 1.0, where values below 0.5 indicate a random fit and values close to 1 mean excellent prediction accuracy. The range value of AUC was sorted into five classes, demonstrating the predictive accuracy of the map: $0.9-1.0$ means excellent, $0.8-0.9$ means very good, $0.7-0.8$ means good, $0.6-0.7$ means average and $0.5-0.6$ means poor (Yesilnacar, 2005). On the other hand, for the consideration of the ideal landslide suspectiblity map, the FR value must have a greater value in very high susceptibility zones and it gradually decreased to a very low susceptibility zone (Tsangaratos and Ilia, 2016; Mondal and Mandal, 2017a, Mondal and Mandal, 2017b). 
Table 3. Factors weight, sub class ranking and FR value.

\begin{tabular}{|c|c|c|c|c|c|c|c|c|c|c|c|c|c|}
\hline Factors & Subclasses & $\begin{array}{l}\text { Subclasses } \\
\text { rank }\end{array}$ & $\begin{array}{l}\text { Factor } \\
\text { weight } \\
\text { of DD } \\
\text { method }\end{array}$ & $\begin{array}{l}\text { Factor } \\
\text { weight } \\
\text { of RD } \\
\text { method }\end{array}$ & $\begin{array}{l}\text { Factor } \\
\text { weight } \\
\text { of MD } \\
\text { method }\end{array}$ & $\begin{array}{l}\text { FR } \\
\text { value }\end{array}$ & Factors & Subclasses & $\begin{array}{l}\text { Subclasses } \\
\text { rank }\end{array}$ & $\begin{array}{l}\text { Factor } \\
\text { weight } \\
\text { of DD } \\
\text { method }\end{array}$ & $\begin{array}{l}\text { Factor } \\
\text { weight } \\
\text { of RD } \\
\text { method }\end{array}$ & $\begin{array}{l}\text { Factor } \\
\text { weight } \\
\text { of MD } \\
\text { method }\end{array}$ & $\begin{array}{l}\text { FR } \\
\text { value }\end{array}$ \\
\hline \multirow[t]{10}{*}{$\mathrm{Dd}$} & $0-1.31$ & 1 & \multirow[t]{10}{*}{1.000} & \multirow{10}{*}{$\begin{array}{l}\text { Not } \\
\text { used }\end{array}$} & \multirow[t]{10}{*}{1.000} & 0.00 & \multirow[t]{10}{*}{$\mathrm{Df}$} & $0-4.91$ & 1 & \multirow[t]{10}{*}{1.000} & \multirow{10}{*}{$\begin{array}{l}\text { Not } \\
\text { used }\end{array}$} & 0.981 & 0.00 \\
\hline & $1.31-2.61$ & 2 & & & & 0.01 & & $4.91-11.05$ & 2 & & & & 0.36 \\
\hline & $2.61-3.67$ & 3 & & & & 1.00 & & $11.05-15.96$ & 3 & & & & 2.17 \\
\hline & $3.67-4.56$ & 4 & & & & 1.97 & & $15.96-21.27$ & 4 & & & & 0.99 \\
\hline & $4.56-5.39$ & 5 & & & & 1.38 & & $21.27-27.00$ & 5 & & & & 0.92 \\
\hline & $5.39-6.27$ & 6 & & & & 1.29 & & $27.00-33.54$ & 6 & & & & 1.87 \\
\hline & $6.27-7.28$ & 7 & & & & 1.46 & & $33.54-40.90$ & 7 & & & & 4.37 \\
\hline & $7.28-8.58$ & 8 & & & & 1.85 & & $40.90-52.35$ & 8 & & & & 0.69 \\
\hline & $8.58-10.60$ & 9 & & & & 0.87 & & $52.35-70.35$ & 9 & & & & 2.76 \\
\hline & $10.60-15.10$ & 10 & & & & 2.94 & & $70.35-104.30$ & 10 & & & & 4.59 \\
\hline Din & $0-1.51$ & 1 & 0.638 & Not & 0.671 & 0.00 & $\mathrm{Di}$ & $.06-.13$ & 1 & Not & 0.588 & 0.452 & 0.10 \\
\hline & $1.51-3.02$ & 2 & & used & & 0.46 & & $.13-.17$ & 2 & used & & & 1.43 \\
\hline & $3.02-4.16$ & 3 & & & & 1.74 & & $.17-.22$ & 3 & & & & 0.22 \\
\hline & $4.06-5.67$ & 4 & & & & 1.60 & & $.22-.26$ & 4 & & & & 0.29 \\
\hline & $5.67-8.12$ & 5 & & & & 1.35 & & $.26-.31$ & 5 & & & & 0.45 \\
\hline & $8.12-12.10$ & 6 & & & & 0.58 & & $.31-.37$ & 6 & & & & 0.40 \\
\hline & $12.10-17.96$ & 7 & & & & 0.23 & & $.37-.42$ & 7 & & & & 1.32 \\
\hline & $17.96-25.51$ & 8 & & & & 0.00 & & $.42-.47$ & 8 & & & & 2.92 \\
\hline & $25.51-34.58$ & 9 & & & & 0.00 & & $.47-.52$ & 9 & & & & 5.29 \\
\hline & $34.58-48.17$ & 10 & & & & 0.00 & & $.52-.59$ & 10 & & & & 0.89 \\
\hline $\mathrm{Dt}$ & $0-1.23$ & 1 & 1.000 & Not & 0.981 & 0.00 & Jf & $0-2.38$ & 1 & 0.971 & Not & 0.935 & 0.00 \\
\hline & $1.23-2.76$ & 2 & & used & & 0.36 & & $2.38-5.82$ & 2 & & used & & 0.21 \\
\hline & $2.76-3.99$ & 3 & & & & 2.17 & & $5.82-9.00$ & 3 & & & & 2.63 \\
\hline & $3.99-5.32$ & 4 & & & & 0.99 & & $9.00-12.45$ & 4 & & & & 0.80 \\
\hline & $5.32-6.75$ & 5 & & & & 0.92 & & $12.45-16.42$ & 5 & & & & 0.81 \\
\hline & $6.75-8.38$ & 6 & & & & 1.87 & & $16.42-20.92$ & 6 & & & & 3.38 \\
\hline & $8.38-10.23$ & 7 & & & & 4.37 & & $20.92-26.74$ & 7 & & & & 1.84 \\
\hline & $10.23-13.10$ & 8 & & & & 0.69 & & $26.74-34.95$ & 8 & & & & 1.19 \\
\hline & $13.10-17.59$ & 9 & & & & 2.76 & & $34.95-46.33$ & 9 & & & & 3.41 \\
\hline & $17.59-26.07$ & 10 & & & & 4.59 & & 46.33-67.49 & 10 & & & & 4.52 \\
\hline In & $0-30.89$ & 1 & 0.891 & Not & 0.836 & 0.01 & $\mathrm{Rb}$ & $1.50-2.56$ & 1 & 0.707 & 0.831 & 0.765 & 0.00 \\
\hline & $30.89-80.32$ & 2 & & used & & 1.76 & & $2.56-3.25$ & 2 & & & & 0.18 \\
\hline & $80.32-148.28$ & 3 & & & & 0.92 & & $3.25-3.71$ & 3 & & & & 1.63 \\
\hline & $148.28-234.78$ & 4 & & & & 1.54 & & $3.71-4.01$ & 5 & & & & 4.14 \\
\hline & $234.78-339.81$ & 5 & & & & 3.13 & & $4.01-4.22$ & 6 & & & & 0.82 \\
\hline & $339.81-481.92$ & 6 & & & & 1.63 & & $4.22-4.52$ & 8 & & & & 0.38 \\
\hline & $481.92-667.27$ & 7 & & & & 2.09 & & $4.52-4.98$ & 9 & & & & 0.42 \\
\hline & $667.27-883.51$ & 8 & & & & 3.11 & & $4.98-5.66$ & 10 & & & & 0.31 \\
\hline & $883.51-1130.66$ & 9 & & & & 5.47 & & & & & & & \\
\hline & $1130.66-1575.50$ & 10 & & & & 3.63 & & & & & & & \\
\hline $\mathrm{Rr}$ & $5.19-51.70$ & 1 & 0.769 & 1.000 & 0.895 & 0.00 & $\mathrm{Ri}$ & $0-.34$ & 1 & 0.967 & 0.890 & 1.000 & 0.00 \\
\hline & $51.70-127.00$ & 2 & & & & 0.00 & & $.34-.93$ & 2 & & & & 0.04 \\
\hline & $127.00-215.00$ & 3 & & & & 0.08 & & $.93-1.42$ & 3 & & & & 0.21 \\
\hline & $215.00-292.00$ & 4 & & & & 0.25 & & $1.42-1.83$ & 4 & & & & 0.57 \\
\hline & $292.00-346.00$ & 5 & & & & 0.88 & & $1.83-2.22$ & 5 & & & & 1.78 \\
\hline & $346.00-393.00$ & 6 & & & & 0.74 & & $2.22-2.63$ & 6 & & & & 3.53 \\
\hline & $393.00-434.00$ & 7 & & & & 0.51 & & $2.63-3.12$ & 7 & & & & 1.56 \\
\hline & $434.00-475.00$ & 8 & & & & 1.43 & & $3.12-3.74$ & 8 & & & & 2.85 \\
\hline & $475.00-532.00$ & 9 & & & & 1.69 & & $3.74-4.48$ & 9 & & & & 1.38 \\
\hline & $532.00-662.00$ & 10 & & & & 10.33 & & $4.48-6.55$ & 10 & & & & 0.24 \\
\hline $\mathrm{E}$ & $106-298$ & 1 & Not & 0.851 & 0.848 & 0.00 & $\mathrm{~S}$ & $0-5.03$ & 1 & Not & 0.811 & 0.720 & 0.04 \\
\hline & $298-539$ & 2 & used & & & 0.59 & & $5.03-11.30$ & 2 & used & & & 0.37 \\
\hline & $539-792$ & 3 & & & & 1.99 & & $11.30-16.80$ & 3 & & & & 0.73 \\
\hline & $792-1030$ & 4 & & & & 2.20 & & $16.80-21.90$ & 4 & & & & 0.98 \\
\hline & $1030-1240$ & 5 & & & & 2.46 & & $21.90-26.60$ & 5 & & & & 0.89 \\
\hline & $1240-1440$ & 6 & & & & 0.92 & & $26.60-31.10$ & 6 & & & & 1.13 \\
\hline & 1440-1650 & 7 & & & & 0.49 & & $31.10-35.50$ & 7 & & & & 1.48 \\
\hline & $1650-1880$ & 8 & & & & 0.16 & & $35.50-40.60$ & 8 & & & & 2.22 \\
\hline & $1880-2130$ & 9 & & & & 0.47 & & $40.60-47.00$ & 9 & & & & 4.42 \\
\hline & $2130-2600$ & 10 & & & & 2.67 & & $47.00-71.10$ & 10 & & & & 13.57 \\
\hline Rra & .02 & 1 & Not & 0.878 & Not & 0.00 & $\mathrm{Hi}$ & $.18-.31$ & 1 & Not & 0.602 & 0.527 & 0.35 \\
\hline & $.02-.11$ & 2 & used & & used & 0.23 & & $.31-.37$ & 2 & used & & & 0.39 \\
\hline & $.11-.14$ & 3 & & & & 0.15 & & $.37-.41$ & 3 & & & & 0.41 \\
\hline & $.14-.18$ & 4 & & & & 2.37 & & $.41-.44$ & 4 & & & & 0.55 \\
\hline & $.18-.20$ & 5 & & & & 0.08 & & $.44-.48$ & 5 & & & & 0.87 \\
\hline & $.20-.21$ & 6 & & & & 2.01 & & $.48-.51$ & 6 & & & & 0.54 \\
\hline & $.21-.22$ & 7 & & & & 3.09 & & $.51-.54$ & 7 & & & & 0.97 \\
\hline & $.22-.23$ & 8 & & & & 0.01 & & $.54-.57$ & 8 & & & & 1.47 \\
\hline & $.23-.27$ & 9 & & & & 0.10 & & $.57-.62$ & 9 & & & & 2.98 \\
\hline & $.27-.30$ & 10 & & & & 0.13 & & $.62-.75$ & 10 & & & & 3.59 \\
\hline
\end{tabular}




\section{Results and discussion}

\subsection{Relationship between morphometric parameters and landslide susceptibility}

The relationship between morphometric parameters and landslide susceptibility has been done using FR value.

\subsection{1. $\mathrm{Dd}, \mathrm{Df}, \mathrm{Rb}, \mathrm{Rr}$ and their landslide potentiality}

It can be observed that Dd in the range of 10.60 15.10 has the highest FR value of 2.94, representing the greater probability of movement of materials down the slope. Also, the Dd classes of 3.67 - 4.56 (1.97), 7.28 - 8.58 (1.85), 6.27 - 7.28 (1.46), 4.56 - 5.39 (1.38) and $5.39-6.27$ (1.29) have a strong relationship with landslides events. On the other hand, the probability of landslide decreased in the Dd class of 0 - 1.31 (0.00) (Table 3). In the Df map, the class of $70.35-104.30$ had the maximum probability of $\mathrm{S}$ failure events (4.59), followed by $52.35-70.35$ (2.76), 11.05 - 15.96 (2.17), 27.00 - 33.54 (1.87), 15.96 - 21.27 (0.99), 21.27 - 27.00 (0.92), 40.90 - 52.35 (0.69), 4.91 11.05 (0.36) and $0-4.91(0.00)$, respectively (Table 3$)$. A $\mathrm{Rb}$ of 3.71 - 4.01 has highest FR value of 4.14, representing the maximum chance of landslide occurrences in future containing $42.10 \%$ of landslide pixels to the total pixels followed by classes of 3.25 - 3.71 (1.63), 4.01 - 4.22 (0.82), 4.52 - 4.98 (0.42), etc., respectively. On the other hand, the lowest probability of landslide occurrences was found in the class of $1.50-2.56(0.00)$, having $0.05 \%$ of landslide pixels (Table 3 ). In the case of relative relief, the class of 532.00 - 662.00 registered a maximum FR value of 10.33, representing a greater probability of landslide phenomena over $34.51 \%$ of landslide area, followed by $475.00-532.00$ (1.69), 434.00 - 475.00 (1.43), etc., respectively. The lowest landslide probability was found in the classes of 5.19 - $51.70(0.00)$ and $51.70-127.00(0.00)$ (Table 3). The trend line of FR value reveals that $\mathrm{Dd}$, Df and $\mathrm{Rr}$ were positively correlated with $\mathrm{S}$ failure, which means that $\mathrm{S}$ instability increases as this value increases. On the other hand, there was negative relation between $\mathrm{Rb}$ and landslide occurrences.

\subsubsection{Din, Dt, Jf, In and their role in $S$ instability}

The Din class of $3.02-4.16$ has the larger FR value of 1.74 , which indicates a maximum $\mathrm{S}$ instability condition in future, with $57.26 \%$ of landslides. Similarly, the classes of 4.06 - $5.67(1.60)$ and $5.67-8.12(1.35)$ have the high probability of materials sliding. On the other hand, the classes of 0 - $1.51(0.00), 17.96-25.51(0.00), 25.51$ $34.58(0.00)$ and $34.58-48.17(0.00)$ were characterised by a minimum probability of $\mathrm{S}$ failure events (Table 3 ). The highest probability was found in the Dt class of 17.59 - 26.07, having an FR value of 4.59 followed by 8.38 10.23 (4.37), 13.10 - 17.59 (2.76), 2.76 - 3.99 (2.17), 6.75 - 8.38 (1.87) etc., respectively. The lowest probability of landslide occurrences was found in the class of $0-1.23$ (0.00) (Table 3). For the Jf, the class of 46.33 - 67.49 has the highest FR value at 4.52 , indicating a strong association with $\mathrm{S}$ failure events. Similarly, the class of $0-2.38$ has the lowest impact on landslide occurrences with a FR value of 0.00 accounting $0.14 \%$ of the total landslide area (Table 3 ). In the case of In, the class of 883.51 - 1130.66 acquired highest degree of FR value of 5.47. The classes of 1130.66 - 1575.50 (3.63), 234.78 - 339.81 (3.13), 667.27 - 883.51 (3.11) and $481.92-667.27$ also have the high probability of landslide occurrences. 0 - 30.89 class has the least degree (0.01) of association with landslides (Table 3 ).

In general, the chance of landslide occurrences reduces with increasing Din. On the other hand, Dt, Jf and In were positively linked with $\mathrm{S}$ failure.

\subsection{3. $R i, \mathrm{Di}$, altitude, $S$ and their role in $S$ failure}

For Ri, the highest FR value of 3.53 was obtained in the class of $2.22-2.63$, which shows greater potentiality for $\mathrm{S}$ failures. The classes of 3.12 - 3.74 (2.85), $1.83-2.22$ (1.78), 2.63 - 3.12 (1.56) and 3.74 - 4.48 (1.38) also have a stronger relationship with landslides. The least probability of landslide occurrences was found in the class of $0-.34$ $(0.00)$ (Table 3 ). In the case of Di, the class of $.47-.52$ acquired the highest FR value of 5.29 , covering $33.71 \%$ of the landslide area to the total landslide area, followed by .42 - .47 (2.92), .13 - .17 (1.43), .37 - .42 (1.32), .52 - .59 (0.89), .26 - .31 (0.45), .31 - .37 (0.40), .22 - .26 (0.29), .17$.22(0.22)$ and $.06-.13(0.10)$, respectively (Table 3$)$. It can be observed that elevation in the range of $2130 \mathrm{~m}-2600 \mathrm{~m}$ has the highest FR value of 2.67 and represents a greater probability of movement of materials down the S. Also, the classes of $1030 \mathrm{~m}$ - $1240 \mathrm{~m}$ (2.46), $792 \mathrm{~m}$ - $1030 \mathrm{~m}$ (2.20) and $539 \mathrm{~m}-792 \mathrm{~m}$ (1.99) have a stronger relationship with landslides events. On the other hand, the probability of landslides was lessened in the elevation class of $106 \mathrm{~m}$ $298 \mathrm{~m}$ (0.00) (Table 3). S angle of $47.00^{\circ}-71.10^{\circ}$ has the highest FR value of 13.57, representing a maximum chance of landslide occurrences in future, containing $13.44 \%$ of landslide pixels to the total pixels followed by $\mathrm{S}$ ranges of $40.60^{\circ}-47.00^{\circ}(4.42), 35.50^{\circ}-40.60^{\circ}$ (2.22), $22.03^{\circ}$ $-25.03^{\circ}(1.48)$, etc., respectively. On the other hand, the lowest probability of landslide occurrences was found in the class of $0^{\circ}-5.03^{\circ}(0.04) \mathrm{S}$ range (Table 3$)$. In general, all four factors were positively associated with $\mathrm{S}$ instability. If the value of the factors increases, the chance of landslide also increases.

\subsubsection{Rra, Hi and their role in landslide occurrences}

In the Rra layer, the highest FR value (3.09) was observed in the class of .21 - .22, indicating greater probability of landslide occurrences. The other classes of .14 - .18 (2.37) and .20 - .21 (2.01) also have a high probability of $\mathrm{S}$ failure. On the other hand, the lowest probability of landslides was observed in the class of .02 
with FR value of 0.00 (Table 3 ). The FR value of the Hi showed that the class of $.62-.75$ has the most effect on the incidence of landslides with an FR value of 3.59 , followed by the classes of $.57-.62(2.98), .54-.57$ (1.47), .51 - .54 (0.97), .44 - .48 (0.87), .41 - .44 (0.55), .48 - .51 (0.54), .37 $.41(0.41), .31-.37(0.39)$ and $.18-.31(0.35)$, respectively (Table 3). Generally, the chance of landslide occurrences increases with the increasing value of the Rra and $\mathrm{Hi}$.

\subsection{Landslide susceptibility mapping using $D D, R D$ and MD models}

Landslide susceptibility maps based on the three different models were prepared using PCA-based weight and their composite equations were presented in Table 2.

The DD model was prepared to identify highly diversified drainage area where geomorphic process is actively engaged in landform modification, whereas the RD model was constructed to find out probable areas where landslide might strike based on the relief configuration parameters. Finally, the MD model was prepared by using drainage and relief parameters.

In this study, the values of the landslide susceptibility map using the DD model varied from 7.94 - 88.46, with the higher value indicating greater possibility of landslide occurrences and vice versa. For visual interpretation, the continuous landslide susceptibility value was classified into five different categorical landslides susceptibility zones using the natural breaks classification method, i.e. very low (7.94 - 16.47), low (16.47 - 27.52), moderate (27.52 - 36.68), high (36.68 - 47.73) and very high (47.73 - 88.46) (Figure 4(a)), covering an area of $22.67 \%$, $15.88 \%, 31.16 \%, 22.07 \%$ and $8.22 \%$, respectively, of the total area of the Balason river basin (Table 4). It was seen that $77.14 \%$ of landslide pixels were found in very high and high susceptibility zones, while the minimum figure lies in the class of very low susceptibility zones $(0.05 \%)$ (Table 4). Similarly, both the landslide susceptibility values of RD and MD models were divided into five different classes using the natural breaks classification method (Figures 4(b) and 4(c)). The very low, low, moderate, high and very high susceptibility zones covered an area of $17.50 \%, 9.61 \%, 22.10 \%, 33.30 \%$ and $17.49 \%$, respectively, using the RD model. In case of the MD model, these zones covered $22.57 \%, 15.11 \%, 31.98 \%$, $22.36 \%$ and $7.98 \%$, respectively (Table 4 ). The proportion of landslide pixels to total landslide pixels decreased from very high to very low susceptibility zones using RD model. About $70 \%$ of landslide pixels were confined to the very low to moderate susceptibility classes using the MD model (Table 4).
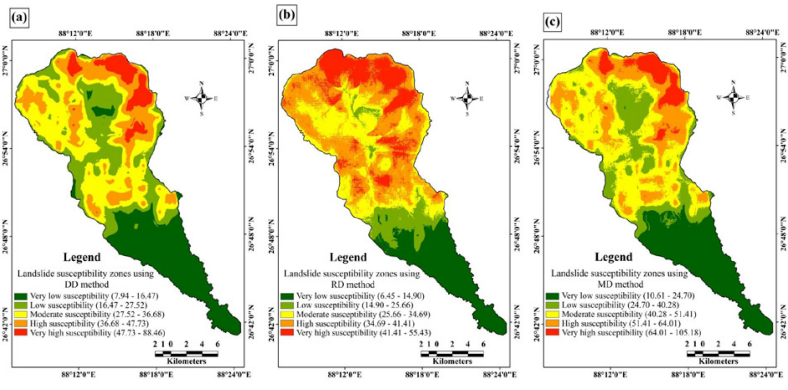

Figure 4. Landslide suspectibility zonation mapping using (a) DD; (b) RD; and (c) MD metway.

Table 4. Statistics of different susceptibility classes of the prepared landslide susceptibility maps using RD, DD and MD methods.

\begin{tabular}{|c|c|c|c|c|c|c|c|}
\hline \multicolumn{3}{|c|}{ Landslide susceptibility zones } & Very low & Low & Moderate & High & $\begin{array}{l}\text { Very } \\
\text { high }\end{array}$ \\
\hline \multirow{5}{*}{$\begin{array}{l}\text { Using } \\
\text { DD } \\
\text { method }\end{array}$} & \multirow[b]{2}{*}{ Total pixels } & Absolute & 381311 & 267158 & 524092 & 371199 & 138240 \\
\hline & & Percentage & 22.67 & $\begin{array}{ll}15.88 \\
\end{array}$ & 31.16 & 22.07 & 8.22 \\
\hline & \multirow{2}{*}{\begin{tabular}{|l|} 
Landslide \\
occurrence \\
pixels
\end{tabular}} & Absolute & 3 & 195 & 1056 & 3000 & 1233 \\
\hline & & Percentage & 0.05 & 3.56 & 19.25 & 54.67 & 22.47 \\
\hline & \multicolumn{2}{|l|}{ FR value } & 0.00 & 0.22 & 0.62 & 2.48 & 2.73 \\
\hline \multirow{5}{*}{$\begin{array}{l}\text { Using } \\
\text { RD } \\
\text { method }\end{array}$} & \multirow[t]{2}{*}{ Total pixels } & Absolute & 294320 & 161612 & 371767 & 560142 & 294159 \\
\hline & & Percentage & 17.50 & 9.61 & 22.10 & 33.30 & 17.49 \\
\hline & \multirow{2}{*}{\begin{tabular}{|l|} 
Landslide \\
occurrence \\
pixels
\end{tabular}} & Absolute & 1 & 49 & 219 & 2087 & 3132 \\
\hline & & Percentage & 0.02 & 0.89 & 3.98 & 38.03 & 57.08 \\
\hline & \multicolumn{2}{|l|}{ FR value } & 0.00 & 0.09 & 0.18 & 1.14 & 3.26 \\
\hline \multirow{5}{*}{$\begin{array}{l}\text { Using } \\
\text { MD } \\
\text { method }\end{array}$} & \multirow{2}{*}{ Total pixels } & Absolute & 379664 & 254090 & 537934 & 376104 & 134208 \\
\hline & & Percentage & 22.57 & 15.11 & 31.98 & 22.36 & 7.98 \\
\hline & \multirow{2}{*}{\begin{tabular}{|l|} 
Landslide \\
occurrence \\
pixels \\
\end{tabular}} & Absolute & 3 & 124 & 1121 & 3000 & 1233 \\
\hline & & Percentage & 0.05 & 2.26 & 20.43 & 54.67 & 22.47 \\
\hline & \multicolumn{2}{|l|}{ FR)value } & 0.00 & 0.15 & 0.64 & 2.45 & 2.82 \\
\hline
\end{tabular}

\subsection{Validation and accuracy assessment}

The AUC value of the ROC curve indicated that the prediction accuracy of the DD, RD and MD models was $71.4 \%, 73.9 \%$ and $76.3 \%$, respectively (Figure 5(a)). The FR plot of the aforementioned three models indicated that the chance of landslide occurrences gradually increases from very low to very high susceptibility class (Figure 5(b) and Table 4). The two-validation procedures showed that the DD, RR and MD models yield reasonable prediction accuracy and can be used for identifying the role of drainage, relief and morphometric parameters in landslide susceptibility assessment. It can be mentioned here that the findings of Mondal and Mandal (2017a) and Mondal and Mandal (2017b) and their work on the Balason river basin suggests that the prediction accuracy of the landslide susceptibility maps was higher using FR and logistic regression (LR) models $(94.20 \%$ and $96.10 \%$, respectively). They incorporated several geomorphological, lithological, hydrological, protective, anthropogenic and triggering factors in the preparation of landslide susceptibility maps. 

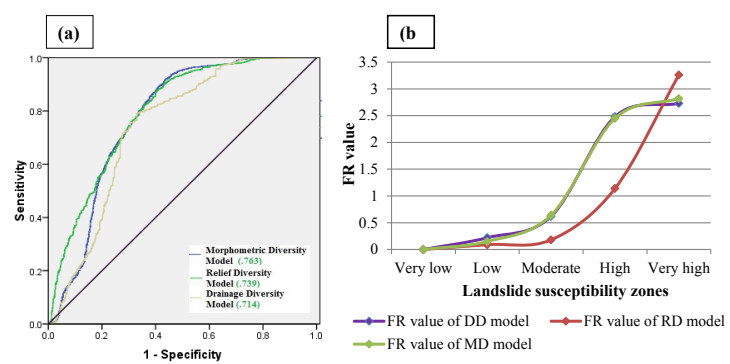

Figure 5. Validation of the landslide susceptibility maps using landslide locations (a) ROC curve and (b) FR plot.

\subsection{Limitations of the prepared landslide susceptibility maps}

The prepared landslide susceptibility maps do not define the chronological characteristics of $\mathrm{S}$ failure events and detailed risk zones. The susceptibility maps should be viewed at the initial landslide mapping. This study does not delineate the areas which become unstable during an earthquake. In addition, the limitations of the study also include an incomplete landslide inventory map due to the restriction of air photos and lack of information about past landslides, generation of errors in the model due to scale and mapping roughness of the landslide causative factors.

\section{Conclusion}

It can be concluded that each model can be treated as unique in terms of terrain processes and forms, and can be used to identify the role of drainage and relief in S failures individually. The DD model on its own predicts $71.40 \%$ of landslides, whereas the RD model predicts $73.9 \%$ of landslides. Landslide prediction is slightly better when $\mathrm{DD}$ and $\mathrm{RD}$ are examined together. The MD model (a combination of RD and DD) has an area ratio .763 and predicts $76.3 \%$ of landslides. However, one must be careful while using these geomorphic diversity models for specific site development because of the scale of analysis where other $\mathrm{S}$ factors need to be considered.

\section{Note on Contributors}

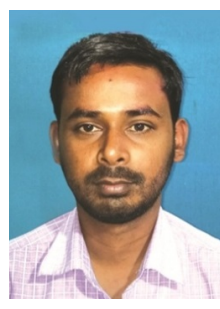

Mr Subrata Mondal has been an Assistant Professor of Geography at A.B.N Seal College, Cooch Behar, India since 2019. He completed his B.A. and M.A. degrees from the University of Gour Banga, West Bengal, India. He is the author of five research articles published in journals by Springer and Taylor \& Francis, and several research articles submitted to reputable international journals. $\mathrm{He}$ is the author of two books, published by Springer. He completed his M.Phil. degree, entitled "Slope instability analysis and delineation of potential landslide susceptibility zones of the Balason river basin in Darjeeling Himalaya, West Bengal" from the University of Gour Banga, West Bengal, India in 2017. At present, he is pursuing a Ph.D. He participated in several national and international seminars and conferences and presented research papers on landslides in Darjeeling Himalaya.

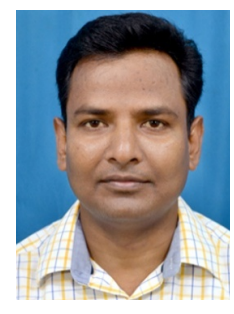

Prof Sujit Mandal is a Professor of Geography at Diamond Harbour Women's University, West Bengal, India since 2005. He completed B.Sc. and M.Sc. degrees from Calcutta University, as well as his Ph.D. thesis, entitled "An analysis of Slope instability in the Shivkhola Watershed of Darjeeling Himalaya: A scientific approach towards the management of land, water and soil". During his teaching career, he participated and presented papers in 30 national and international seminars and conferences on several aspects of landslides. He is the author of 40 research articles published in reputable national and international journals, of which 12 have been published by Springer and two by Taylor \& Francis. He is the first author of the book Semi-quantitative approaches for Landslide Susceptibility Assessment and Prediction, published by Springer Publishing House. He is also the principal investigator of one minor research project sponsored by university grants commission and one major research project sponsored by Indian Council of Social Science Research.

\section{References}

[1] Akgun A, Sezer EA, Nefesliogl HA, Gokceoglu C and Pradhan B (2012). An easy-to-use MATLAB program (MamLand) for the assessment of landslide susceptibility using a Mamdani fuzzy algorithm. Comput Geosci, 38, pp. 23-34.

[2] Althuwaynee OF, Pradhan B, Park H and Lee JH (2014). A novel ensemble bivariate statistical evidential belief function with knowledge-based analytical hierarchy process and multivariate statistical logistic regression for landslide susceptibility mapping. Catena, 114, pp. 21-36.

[3] Amani M and Safaviyan A (2015). Sub-basins prioritization using morphometric analysisremote sensing technique and GIS-Golestan-Iran. International Letters of Natural Sciences, 38, pp. 5665.

[4] Anbalagan R (1992). Landslide hazard evaluation and zonation mapping in mountainous terrain. Engineering Geology, 32, pp. 269-277.

[5] Avinash K, Deepika B and Jayappa KS (2014). Basin geomorphology and drainage morphometry parameters used as indicators for groundwater prospect: Insight from geographical information system (GIS) Technique. Journal of Earth Science, 25(6), pp. 1018-1032. 
[6] Ayalew L, Yamagishi H, Marui H and Kanno T (2005). Landslides in Sado island of Japan: part II, GIS-based susceptibility mapping with comparisons of results from two methods and verifications. Engineering Geology, 81, pp. 432-445.

[7] Bui DT, Pradhan B, Lofman O, Revhaug I and Dick OB (2012). Spatial prediction of landslide hazards in Hoa Binh province (Vietnam): A comparative assessment of the efficacy of evidential belief functions and fuzzy logic models. Catena, 96, pp. 28-40.

[8] Chau KT, Sze YL, Fung MK, Wong WY, Fong EL and Chan LCP (2004). Landslide hazard analysis for Hong Kong using landslide inventory and GIS. Computers \& Geosciences, 30, pp. 429-443.

[9] Choi J, Oh HJ, Lee HJ, Lee C and Lee S (2011). Combining landslide susceptibility maps obtained from frequency ratio logistic regression and artificial neural network models using aster images and GIS. Engineering Geology, 124, pp. 12-23.

[10] Devkota KC, Regmi AD, Pourghasemi HR, Yoshida K, Pradhan B, Ryu IC, Dhital MR and Althuwaynee OF (2013). Landslide susceptibility mapping using certainty factor index of entropy and logistic regression models in GIS and their comparison at Mugling-Narayanghat road section in Nepal Himalaya. Natural Hazards, 65, pp. 135-165.

[11] Faniran A (1968). The index of drainage intensity - A provisional new drainage factor. Australian Journal of Science, 31, pp. 328-330.

[12] Farhan Y, Anbar A, Enaba O and Al-Shaikh N (2015). Quantitative analysis of geomorphometric parameters of Wasi Kerak, Jordan, using remote sensing and GIS. Journal of Water Resource and Protection, 7, pp. 456475.

[13] Gajbhiye S, Mishra SK and Pandey A (2014). Prioritizing erosion-prone area through morphometric analysis: An RS and GIS perspective. Applied Water Science, 4(1), pp. 51-61.

[14] Ghosh D (2015). Landslide susceptibility analysis from morphometric parameter analysis of riyong khola basin, west sikkim, india: a geospatial approach. International Journal of Geology, 5(1), pp. 54-65.

[15] Ghosh S, Carranza EJM, van Westen CJ, Jetten VG and Bhattacharya DN (2011). Selecting and weighting spatial predictors for empirical modeling of landslide susceptibility in the Darjeeling Himalayas (India). Geomorphology, 131(1-2), pp. 35-56.

[16] Gopal KG and Saha S (2015). Identification of soil erosion susceptible areas in Hinglo river basin, Eastern India based on geostatistics. Universal Journal of Environmental Research and Technology, 5(3), pp. 152-164.

[17] Gupta RP and Joshi BC (1990). Landslide hazard zonation using the GIS approach-A case Study from the Ramganga Catchment Himalayas. Engineering Geology, 28, pp. 119-131.
[18] Horton RE (1945). Erosional development of streams and their drainage basins, a hydrophysical approach to quantitative morphology. Geological Society of American Bulletin, 56, pp. 275-370.

[19] Jeganathan C and Chauniyal DD (2000). An evidential weighted approach for landslide hazard zonation from geo-environmental characterization: A case study of Kelani area. Current Science, 79(2), pp. 238-243.

[20] Karim S, Jalileddin S and Ali MT (2011). Zoning landslide by use of frequency ratio method (case study: Deylaman Region). Middle-East Journal of Scientific Research, 9(5), pp. 578-583.

[21] Khatun S and Pal S (2017). Categorization of morphometric surface through morphometric diversity analysis in Kushkarani River Basin of Eastern India. Asian Journal of Physical and Chemical Sciences, 2(1), pp. 1-19.

[22] Lama IL (2003). Study of the environmental geomorphology in the Balason Basin. Ph.O. North Bengal University.

[23] Lee S and Pradhan B (2007). Landslide hazard mapping at Selangor Malaysia using frequency ratio and logistic regression models. Landslides, 4, pp. 33-41.

[24] Lee S and Sambath T (2006). Landslide susceptibility mapping in the Damrei Romel area Cambodia using frequency ratio and logistic regression models. Environmental Geology, 50, pp. 847-855.

[25] Lee S and Talib JA (2005). Probabilistic landslide susceptibility and factor effect analysis. Environmental Geology, 47, pp. 982-990.

[26] Magesh NS, Jitheshlal K, Chandrasekar N and Jini $\mathrm{K}$ (2012). GIS based morphometric evaluation of Chimini and Mupily watersheds, parts of Western Ghats, Thrissur district, Kerala, India. Earth Science Informatics, 5, pp. 111-121.

[27] Majtan S, Omura H and Morita K (2002). Fractal dimension as an indicator of probability for landslides in North Matsuura Japan. Geograficky Casopis, 54, pp. 5-19.

[28] Mandal B and Mandal S (2016). Assessment of mountain slope instability in the Lish river basin of Eastern Darjeeling Himalaya using frequency ratio model (FRM). Earth Systems and Environment, 2, p. 121.

[29] Mandal S and Mandal K (2017). Bivariate statistical index for landslide susceptibility mapping in the Rorachu river basin of eastern Sikkim Himalaya, India. Spatial Information Research, 26 (1), pp. 59-75.

[30] Mandal S and Mandal K (2018). Modeling and mapping landslide susceptibility zones using GIS based multivariate binary logistic regression (LR) model in the Rorachu river basin of eastern Sikkim Himalaya, India. Modeling Earth Systems and Environment, 4 (1), pp. 69-88. 
[31] Miller JR, Ritter DF and Kochel RC (1990). Morphometric assessment of lithologic controls on drainage basin evolution in the Crawford Upland, South-Central Indiana. America Journel of Science, 290, pp. 569-599.

[32] Miller VC (1953). A quantitative geomorphic study of drainage basin characteristics in the Clinch mountain area. Virginia and Tennessee: Deptt. of Geology, Columbia University.

[33] Mohammady M, Pourghasemi HR and Pradhan B (2012). Landslide susceptibility mapping at Golestan Province, Iran: A comparison between frequency ratio, dempster-shafer, and weights-of-evidence models. Journal of Asian Earth Sciences, 61, pp. 221-236.

[34] Mondal S and Mandal S (2017a). Application of frequency ratio (FR) model in spatial prediction of landslides in the Balason river basin, Darjeeling Himalaya. Spatial Information Research, 25, pp. 337350.

[35] Mondal S and Mandal S (2017b). RS \& GIS-based landslide susceptibility mapping of the Balason River basin, Darjeeling Himalaya, using logistic regression (LR) model. Georisk: Assessment and Management of Risk for Rngineered Systems and Geohazards. 12(1), pp. 29-44.

[36] Nautiyal MD (1994). Morphometric analysis of drainage basin, district Dehradun, Uttar Pradesh. Journal of the Indian Society of Remote Sensing, 22, pp. 252-262.

[37] Nefeslioglu HA, Sezer E, Gokceoglu C, Bozkir AS and Duman TY (2010). Assessment of landslide susceptibility by decision trees in the metropolitan area of Istanbul Turkey. Mathematical Problems in Engineering, Article ID: 901095.

[38] Nidhi K, Chowdary VM, Tiwari KN, Shinde V and Dadhwal VK (2016). Assessment of surface water potential using morphometry and curve number-based approaches. Geocarto International, 32(11), pp. 12061228.

[39] Nir D (1957). The ratio of relative and absolute altitude of Mt.Camel. Geographical Review, 47, pp. 564-569.

[40] Ozdemir A and Altural T (2013). A comparative study of frequency ratio, weights of evidence and logistic regression methods for landslide susceptibility mapping: Sultan Mountains, SW Turkey. Journal of Asian Earth Sciences, 64, pp. 180-197.

[41] Pradhan B (2010). Use of GIS-based fuzzy logic relations and its cross application to produce landslide susceptibility maps in three test areas in Malaysia. Environmental Earth Sciences, 63, pp. 329-349.

[42] Pradhan B and Lee S (2010a). Delineation of landslide hazard areas on Penang Island, Malaysia, by using frequency ratio, logistic regression, and artificial neural network models. Environmental Earth Science, 60(5), pp. 1037-1054.
[43] Pradhan B and Lee S (2010b). Landslide susceptibility assessment and factor effect analysis: Backpropagation artificial neural networks and their comparison with frequency ratio and bivariate logistic regression modelling. Environmental Modelling \& Software, 25(6), pp. 747-759.

[44] Rai PK, Mishra S, Ahmad A and Mohan K (2014). A GIS-based approach in drainage morphometric analysis of Kanhar River Basin, India. Applied Water Science, 7, pp. 217-232.

[45] Rastogi RA and Sharma TC (1976). Quantitative analysis of drainage basin characteristics. Journal of Soil and Water Conservation in India, 26 (1\&4), pp.1825.

[46] Sarkar S and Kanungo DP (2004). An integrated approach for landslide susceptibility mapping using remote sensing and GIS. Photogrammetric Engineering \& Remote Sensing, 70(5), pp. 617-625.

[47] Schumm SA (1956). Evolution of drainage systems and slopes in badlands at Perth Amboy, New Jersey, Geological Society of American Bulletin, 67(5), p. 597.

[48] Shrestha S, Kang T and Suwal MS (2017). An ensemble model for co-seismic landslide susceptibility using GIS and random forest method. International Journal of Geo-Information, 6, p. 365.

[49] Song Y, Gong J, Gao S, Wang D, Cui T, Li Y and Wei B (2012). Susceptibility assessment of earthquake induced landslides using Bayesian network: A case study in Beichuan China. Computers \& Geosciences, 42, pp.189-199.

[50] Spiker EC and Gori PL (2000). National landslide hazards mitigation strategy: A framework for loss reduction. US: Department of the interior, U.S. Geological Survey, p. 59.

[51] Strahler AN (1952). Hypsometric (area-altitude) analysis of erosional topography. Geological Society of American Bulletin, 63, pp. 117-142.[65]

[52] Strahler AN (1964). Handbook of Applied Hydrology. United States: McGraw-Hill. pp. 4.39-4.76.

[53] Thakkar AK and Dhiman SD (2007). Morphometric analysis and prioritization of miniwatersheds in Mohr watersheds, Gujarat using remote sensing and GIS techniques. Journal of Indian Society of Remote Sensing, 33(1), pp. 25-38.

[54] Tsangaratos P and Ilia I (2016). Comparison of a logistic regression and native bayes classifier in landslide susceptibility assessments: The influence of models complexity and training dataset size. Catena, 145, pp. 164-179.

[55] Xu C, Dai F, Xu X and Lee YH (2012). GIS-based support vector machine modeling of earthquaketriggered landslide susceptibility in the Jianjiang River watershed China. Geomorphology, 145-146, pp. 70-80.

[56] Yesilnacar EK (2005). The application of computational intelligence to landslide susceptibility mapping in Turkey. Ph.D. University of Melbourne.

[57] Yin K J and Yin TZ (1988). Statistical prediction model for slope instability of metamorphosed rock. In: Proceedings of 5th International Symposium on Landslides. Lausanne: Balkema 2, pp. 1269-1272. 